\title{
Shattering the idols: Confronting the obstinate hold of dehumanising powers on post-apartheid South Africans with the living presence of the crucified and resurrected Lord
}

\author{
Authors: \\ Ferdinand P. Kruger ${ }^{1}$ \\ Friedrich W. de Wet ${ }^{1}$ \\ Affiliation: \\ ${ }^{1}$ Department of Practical \\ Theology, North-West \\ University, Potchefstroom \\ Campus, South Africa \\ Correspondence to: \\ Ferdinand Kruger \\ Email: \\ ferdi.kruger@nwu.ac.za \\ Postal address: \\ Faculty of Theology, \\ North-West University, \\ Potchefstroom Campus, \\ Potchefstroom, South Africa \\ Dates: \\ Received: 29 Jan. 2015 \\ Accepted: 07 May 2015 \\ Published: 01 July 2015 \\ How to cite this article: \\ Kruger, F.P. \& De Wet, F.W., \\ 2015, 'Shattering the idols: \\ Confronting the obstinate \\ hold of dehumanising powers \\ on post-apartheid South \\ Africans with the living \\ presence of the crucified \\ and resurrected Lord', In die \\ Skriflig 49(1), Art. \#1937, \\ 11 pages. http://dx.doi. \\ org/10.4102/ids.v49i1.1937
}

This practical-theological article focuses on the spiritual dimension of forces that are influencing the social fabric of post-apartheid South Africans. Working with Eswine's assumption, we reflect on the hold of idols on the hearts and minds of people. The spiritual powers at work in society develop into idols and place their own desires above God's purpose for humanity and creation. Rather than serving the ends of human life, the powers exercise dominion over human beings, restricting and dehumanising them and destroying the fabric of integrated social life by means of the blinding and hardening hold of idolatry. In the post-apartheid South African society this idolatry manifests in the illusion of power flowing from entitling oneself to self-aggrandisement and in the false sense of stability flowing from the efforts of the middle class in establishing a sophisticated first-world enclave aimed at protecting themselves from the third-world masses. The purpose is to develop the contours for a homiletic theory aimed at shattering the obstinate hold of idols by means of the prophetic act of ministering the living presence of the crucified and resurrected Christ in the hearts and minds of preachers and listeners. A theory is envisioned for an iconoclast action that originates from a different power and wisdom base than is the case with the dominating forces and the hold of their idols, namely a field of force with the integrating presence of the risen Christ at its heart; a space where a liberated and reconciled humanity will be able to flourish.

Die verbryseling van die afgode: Die konfrontering van die hardnekkige houvas van verontmenslikende kragte op post-apartheid Suid-Afrikaners met die lewende teenwoordigheid van die gekruisigde en opgestane Here. Hierdie prakties-teologiese artikel, fokus op die geestelike dimensie van magte wat in 'n post-apartheid Suid-Afrikaanse samelewing 'n invloed op die sosiale omgewing uitoefen. Die uitgangspunt van Eswine dien as aansporing vir die besinning oor die houvas wat afgode op die harte en gedagtes van gelowiges het. Die funksionering van geestelike magte in die samelewing word ondersoek. Hierdie magte verhef hulself tot afgode en plaas hulle eie begeertes bo God se wil vir die skepping en die mens. In plaas daarvan om God se wil vir die onderhouding van die menslike lewe te eerbiedig oefen hierdie magte heerskappy oor mense uit deur afgodery waardeur die geïntegreerdheid van die samelewing gedisintegreer word. Mense word verblind om die invloed van afgodery in hulle lewens te vestig. In 'n post-apartheid Suid-Afrikaanse samelewing manifesteer dit deur die illusie van mag voortvloeiend uit selfverheerliking, asook in die middelklas se koorsagtige poging om hulleself in 'n gemaklike eerste-wêreldenklawe te isoleer as beskerming teen die Derdewêreldse massas. Die outeurs wil 'n homiletiese teorie vir die verydeling van afgodery ontwerp wat in die teenwoordigheid van die gekruisigde en opgestane Christus in die harte en gedagtes van hoorders gegrond is. Hierdie kragveld open 'n lewensruimte waarin gelowiges, bevry van die mag van afgodery, versoend sal kan floreer.

\section{Introduction}

Proposals for change in a context of dehumanising power structures are usually met with staunch resistance. Understanding why this is the case calls for consideration of the depth of the underlying tension field. In this article, it is argued that one possible way of exploring this depth level involves taking into account the hold of idolatry over the minds and hearts of human beings and the spiritual background into which it is imbedded.

Note: The contribution of F.W. de Wet is based on research supported entirely by the National Research Foundation of South Africa (Grant Number 91018). Any opinion, finding and conclusion or recommendation expressed in this material is that of De Wet and the co-author Kruger and the NRF does not accept any liability in this regard.

Copyright: @ 2015. The Authors. Licensee: AOSIS OpenJournals. This work is licensed under the Creative Commons Attribution License. 
Eswine (2008:218) offers an interesting contribution to this topic by stating: 'We shall never understand the spiritual movements of our own or of any other generation, unless we see that God's controversy with idols and idolatries is the main controversy of the world.' The difficulty in identifying idolatry is that idols are distortions of things that in themselves are good (Keller 2012:82). Tidball (2011:17) reminds us of the famous words of Calvin who spoke of the human mind as a perpetual forge (factory) of idols. Human nature is prone to idolatry. Idols are spiritual addictions that lead to terrible evil (Keller 2009:2). This very fact opens up a tension field in proclaiming the Word of God. During the process of sermon preparation, preachers must identify the good things people (including themselves) tend to cling to that may become overly important in hearers' lives. In this tension field preaching functions has to do with the good news of God's supremacy in a world where lifeless and dethroned idols lead to destruction (Piper 2012:13). The reality behind idolatry is that idols are good things that are distorted into necessities that people cannot live without. People must have it, and therefore it drives them to break rules they once honoured. People become willing to harm others and even themselves to reap the perceived benefits of allegiance to their idols.

One can reckon with the insights of Campbell (2002:24), who discusses the rebellious nature of fallen powers and states that although the powers are created good by God, they live in rebellion against God's purposes. They have repudiated their vocation. Instead of serving God's will and sustaining human life in society, the powers turn into idols and place their own desires above God's purpose for humanity and creation. They do anything in their power to create the illusion that they, and not God, are the divine regents in the world. The beast in the book of Revelation, according to Eswine's (2008:229) interpretation, first and foremost seeks to receive the worship of human beings. Idolatry, then, is the fundamental sin of the fallen powers. The tragedy of idolatry is that it costs others and us. When a scholar in Homiletics interprets the underlying depth level of a sermon's action field from this perspective, the transcendental and eschatological dimensions will play an important role in theory formation. Long (2009:123) reminds us that vibrant Christian preaching depends on the recovery of its eschatological voice. Preaching has therefore the task to share and spread the hope in Christ to the world where idolatry has become a reality. The eschatological tension of already and not yet is important in addressing the topic of the functioning of dehumanising powers. Believers are facing a war against the principalities and authorities of this world, but the outcome is already clear. The church already shares in the victory of Jesus Christ. The powers behind idols have already been conquered in the presence of the living God, but the war of shattering these idols in our minds and hearts is continuing until the final coming of Jesus Christ.

Craddock (1985:65) was first to highlights the challenge preachers are facing, namely that both bad and good preaching will always experience resistance. Craddock also mentions that preachers must respect their hearers' resistance, but in such a manner that a claim is always made upon God in every sermon. Buttrick (1987:113) puts his finger on the spot and describes the essence of preaching as 'calculated God-talk'. Stott (2007:113) expresses his concern about the fact that contemporary society is unfriendly towards preaching (calculated God-talk) and has been called 'an echo from an abandoned past'. Achtemeier (2000:14) shares the regret about this lamentable state and underlines the subjacent difficulty preachers are facing in their sermons when they are communicating to people who often think that God is absent in all spheres of life because of the functioning of so many idols in their lives. Preaching must therefore give direction to hearers and help them to realise that God is the only God of their lives, despite the thought patterns that shape today's world (Dingemans 2005:24-25).

In this article the authors place this universal issue of idolatry's obstinate hold on the hearts and minds of people within a South African context. In a post-apartheid dispensation it is important to realise that changes in the political sphere contributed to different views in other spheres, also in the religious sphere (Van der Walt 1999:124). Two examples of phenomena that we interpret to be examples of the obstinate functioning of idols in a South African environment are discussed.

In the first instance, the effects of the power structures behind the neo-liberal macromanagement policies of the current South African government are examined against the background of the growing number of labour-related protests.

The second example focuses on the rhetoric of the so-called White Talk as a means through which white people attempt to position themselves within an Africanising context, failing to realise that their preoccupation with their own privileges are potentially estranging them from their fellow South Africans in the process.

The main research question is as follows: How can preachers effectively confront the obstinate hold of dehumanising powers and their underlying structures on post-apartheid South Africans with the living presence of the crucified and resurrected Lord?

The methodological insights of Dingemans (1996:91-92) are utilised ${ }^{1}$ to address this problem. An initial description is given of idolatry and the functioning of dehumanising powers, culminating in a discussion on how idolatry is interpreted to function in the problematic praxis of dehumanising power structures in South African society. In the second phase of this investigation, the authors proceed by developing normative perspectives for adequately interpreting and addressing this problem. In the last phase of this investigation the authors provide practical theoretical perspectives for visualising a kind of preaching that will be

1.Dingemans (1996:92) distinguishes four phases in practical theological investigation, namely the analysis of the situation, an explanation of the situation, the normative phase of research and transforming the existing practice. 
able to meet resistance with shattering power without itself becoming dehumanising in the process.

Depicting the obstinate hold of dehumanising powers on human life and society at first glance, it is difficult to imagine an interface for the active functioning of idolatry in the lives of contemporary humanity, and within a South African context. When thinking about idols and idol worship, the ancient idea of bestowing divine attributes to a fabricated image, and showing loyalty to a self-made god in the place of a relation with the one true living God (cf. Beale 2008:17) immediately springs to mind. The degrading effect of idolatry does, however, not seem to be limited to the ways in which ideas took concrete shape in the religious environment of antiquity. The ideas that underlie idolatry seem to be very much alive today. Idolatrous techniques for embodying one's god to make him (or her) available for negotiating beatific benefits (short-term favours, good fortune, and even salvation) still seem to be deployed in contemporary times (cf. Johnston 2009:22; Weidler 2012:493). Idolatry therefore occurs just as often in the western world where there is no literal image to be seen (Tidball 2011:16). In this sense, contemporary expressions of human desire and intent can be interpreted to be representative of idolatrous behaviour; constituting of people giving their idol permission to demand and receive whatever it desires, even if it includes all their time and effort and even their very lives, because they see the idol as their saviour, as the one who can make life whole and bring blessing (cf. Goudzwaard 1984:21)

Legitimate goals that are pursued to give meaning to life, for instance the preservation and expansion of one's prosperity, and the efforts to protect oneself and one's cultural identity against attack from outside, can become ideological goals. This can happen in the sense that these goals are expressed in a kind of idolatry that is allowed to take root in the pursuit of a legitimate end by indiscriminately justifying every means that is needed to obtain a self-preserving and self-expanding end. Legitimate goals, then, become ends in themselves, instead of a means to the end of serving and glorifying God (Tidball 2011:16). An ideology that is obsessed with and driven by self-preservation may, for instance arise in a situation where our well-being and prosperity are threatened. Such a situation, if not eliminated, would cause our death. Without deep-seated causes and motives such an ideology will not generate a genuine movement; a movement in which we are motivated and even driven to think and act in a certain way. Its hold on the minds and hearts of people is anchored in something which is fundamentally wrong and which threatens us mercilessly. The problem with such an ideological orientation, however, is that it seems to cause us to see the presence of other human beings who find themselves outside the immediate circle of our own selfpreserving concern, as threatening and alien. Therefore a kind of ideology that is rooted in self-serving idolatry has the ever-present potential to unleash alienating, discriminating and destructive forces in human society (cf. Goudzwaard 1984:27).
In this sense, idolatry can be seen to have a dehumanising effect by making us so preoccupied with our own needs and interests, that it blinds our minds and hardens our hearts for the kind of relational life that can truly create abundance of life for all. Campbell (2002:8) refers to the classic novel by John Steinbeck, The grapes of wrath, written in the context of landowner's conduct in reaction to the effects of the Great Depression in the USA. Steinbeck (1999) writes:

Some of the owner men were kind because they hated what they had to do, and some of them were angry because they hated to be cruel, and some of them were cold because they had long ago found that one could not be an owner unless one was cold. And all of them were caught in something larger than themselves. Some of them hated the mathematics that drove them, and some were afraid, and some worshipped the mathematics because it provided them a refuge from thought and from feeling ... (pp. 31-32)

This account by Steinbeck gives a rather raw and candid description of the obstinate hold that we can give our idols by allowing ourselves to be driven in such an irresponsible way that we break the basic rules of humaneness, harming others and even - without realising it - ourselves to advance our own ends. Idolatry becomes an egoistic spiritual addiction that leads to terrible evil (cf. Cilliers 2000:135-137; Fouche 1999:28; Keller 2009:2).

In realising the full extent of the tension field that humanity allows itself to be drawn into by idolatry, the article considers a theological perceptual framework for the relationship between the immanent, visible reality we find ourselves in and the transcendental factors that may underlie this visual world. Then the cosmological presence of the fallen powers (cf. Eph 6:12) and their possible influence on our reality will have to be taken into account. This will reveal that the obstinate hold of idols on the hearts and minds of humanity only constitutes the tip of the iceberg, with the vast implications of the active presence of fallen angelic powers hidden beneath the surface. In this we concur with Campbell (2002:25-27) who interprets the fallen powers as beings that, having turned away from God's purpose for their presence, have become relentlessly aggressive against all life, particularly human life in society. Rather than serving the ends of human life, the powers now exercise dominion over human beings, restricting, controlling and consuming them to sustain, extend and prosper their own survival. Both the powers' need to survive and their quest for dominion results in an obstinate hold and find ultimate expression in violence, which takes systemic as well as interpersonal forms and involves psychological and spiritual as well as physical dimensions.

\section{The problematic praxis: Examples of the obstinate power systems in a post-apartheid South African society}

Elshtain (2011:220) reasons that modern political science, in attempting to avoid the horrors of totalitarianism, severs our 
understanding of politics from any normative grounding or metaphysical framework. Trying to tame politics by severing life in the public square from fundamental questions of meaning and value turns politics into a 'charade', cutting off human activity from its constitutive vitality, namely its guiding hopes, fears, and aspirations. The politics that come out of metaphysical rebellion, Elshtain (2011:221) continues reasoning, came into focus with the 'logical delirium' of the French Revolution. By beheading the king, the link to transcendence was finally broken, making the here and now the period before the end time - an absolute, a new deity demanding human sacrifice. We concur with Elshtain that any legitimate study of political life - or any human action field for that matter - cannot work with a neutered vision, as if this field of study merely comprises a closed system of bargaining over finite material goods without taking into account the vital element of human aspirations and the spiritual dimension of the conceptual framework in which these aspirations are imbedded.

We now proceed by discussing two examples of obstinate power systems in the post-apartheid context that are apparently causing deepening tension and widening chasms between fellow South Africans. In the first example the effects of power structures behind the neo-liberal macromanagement policies of the current South African government are examined against the background of the growing number of labour-related protests, especially as it came to a violent expression during the 'Marikana massacre'. Conflict with the police force resulted in the deaths of 44 people, the majority of whom were striking mineworkers, killed on 16 August 2012 at a mine owned by Lonmin in the Marikana area, close to Rustenburg (cf. Satgar 2012:34). In the second example, the focus falls on the rhetoric of the so-called White Talk as a means through which white people attempt to position themselves within an Africanising context, failing to realise that their preoccupation with their own privileges are potentially estranging themselves from their fellow South Africans. In both cases, we wish to ask to what extent a theological point of entry will be able to contribute to an understanding and a countering of the rainbow-nation's dissolving powers that are at work in our society.

According to Bond and Mottair (2013:284), the rash of service delivery protests and labour unrest in South Africa reflects the distorted character of 'growth' that South Africa witnessed after adopting neo-liberal macroeconomic and microdevelopment policies following the demise of apartheid in 1994 (cf. Satgar 2012:35). Factors like poorly developed housing projects (often accompanied by inadequate infrastructure), rapidly rising unemployment, deepening inequality and the ever-rising cost of living are contributing to rising levels of despair and anger. By mid2012 , starting in the mining belt and moving to transport and then the Western Cape farms, periodic explosions of wildcat strike activity by tens of thousands of workers at a time put unprecedented socio-economic stress on post-apartheid South Africa (Bond \& Mottiar 2013:291).
During the events surrounding the Marikana massacre of 2012, the unstable configuration of forces that gradually developed in post-apartheid South Africa reached a boiling point. Bond and Mottair (2013) summarises the underlying tension field surrounding these events as follows:

Beyond just the obvious human rights and labour-relations travesties, the incident offered the potential for a deep political rethink, unveiling extreme depths of ruling-class desperation represented by the fusion of former radical labour leader Cyril Ramaphosa's black capitalism, Lonmin's collaboration (through Ramaphosa) with the mining and police ministers, the brutality of state prosecutors who charged the victims with the crime, the alleged 'sweetheart unionism' of the increasingly unpopular National Union of Mineworkers (NUM), and the fragility of a Cosatu split between Zuma/Ramaphosa loyalists and those with worker interests at heart. Positions quickly hardened. (p. 292)

If it is indeed true that this episode disclosed the extreme depths of ruling-class desperation and a obstinate hardening of positions, the following questions could be asked from a theological viewpoint: To what extent was the brutality and exceeding violence that surfaced during this unfortunate event triggered by a desperate attempt to protect the own idol of self-aggrandisement from being threatened by the masses? (cf. Bongmba 2006:84). Can this episode be interpreted as revealing that one can allow oneself to treat other human beings merely as objects of economic threat rather than as human persons as soon as your own perceived financial independence comes under fire? To what extent were the God-defying fallen powers of evil allowed to fulfil their destructive desires against life in the process? Steyn and Forster (2008) analyse the discursive practices of the so-called White Talk as it is contained in post-apartheid newspaper columns for instance. According to them (2008:26), the central question for whiteness, as the orientation which takes its privilege as normal and appropriate, can be put simply, namely how to maintain its advantages in a situation in which black people have legally and legitimately achieved political power.

On the surface level of White Talk key democratic values like fairness and non-discrimination have to be in place, whilst on the depth level the right to defend the own privileged position is subtly maintained. Rhetorically, this is managed by drawing false parallels that flatten out and conceal ongoing inequalities that should be acknowledged if one's true intention is to bring about a fairer situation. Steyn and Forster (2008:30) refer to a passage written by the Sunday Times columnist Barry Ronge in which the two highly incomparable situations of black people choosing to go to other countries during the 1960s and 1970s and the current exodus of white young people are treated as if they are isomorphic; as if there is a direct comparison between the reason why black people chose to leave and the actions of white young people who want to go where they will find their best opportunities. This parallel then subtly allows the columnist to destigmatise the contemporary exodus, conveniently covering the partakers against accusations as if they were unpatriotic quislings who 
grabbed a privileged education and then zipped off overseas for some selfish profit motive.

Yet again, the question could be asked from a theological perspective: To what extent is the so-called White Talk a construction by the white, privileged middle class in a frantic effort to protect themselves and their children from a destabilised future overrun by the regress of third world mentality, sowing the seeds of misguided perceptions, suspicion and debasing remarks about the integrity of fellow human beings in the process? To what extent has the preservation of the own privileged position becomes an idol opening up opportunities for the fallen powers to deprive people from the joy of enriching the lives of their fellow human beings and heightening the potential for intolerance and hatred in the process?

As an example of a possible theological framework that strives to envision an alternative to destructive patterns in human society, reference can be made to Horstkoetter's conceptualisation regarding the triune gift economy. Horstkoetter (2013:97-99) roots the charge of idolatry directed at the contemporary mammon in the triune gift economy. The over-abundant gift giving of the triune life is manifested in human history as the missio Dei - as the comprehensive actions of the God who gives his own Self to humans all created equal in the imago Dei. The qualities of divine relationality begin to constitute human communal life and expand into an alternative economy that is rooted in loving gift, positive otherness, openness, invitation, stability, and abundance. Rather than a life actualised in bargain, subject to a scarcity model, limited to competition, or valued by arbitrary worth, life is instead valued by divinity's sovereignty and grand abundance (cf. Heisey 2011:49).

In the next section, the contours are drawn for an adequate normative framework that not only introduces transcendent elements in trying to explain destructive patterns in the fabric of human society and depicts an alternative visualisation for human interaction anchored in living community with the triune God, but also contains a theological foundation for the means through which the obstinate hold of dehumanising powers can be shattered.

\section{Normative perspectives on the authoritative presence of the crucified and resurrected Lord}

In this section, normative perspectives from Scripture are explored. The normative phase of this investigation seeks to discern God's will for present realities. In this process of prophetic discernment (cf. Osmer 2008:117) three perspectives are addressed, namely the central perspective about worshipping the living and present God alone; the perspective of faith-participation in the victory of the crucified and resurrected Lord as a means for shattering idols; and the perspective of consciously countering the functioning of the principalities and powers in this world. In addressing these aspects it can be helpful to read what Watts (2012) has to say about idolatry:

Idols are not so much statues before which to bow as other centres of identity, meaning and security in which we trust. Yet an idol is never simply a material object, nor is it without power. The power of the idol is real, but it is human, not divine. It neither honours God nor ennobles people. (p. 28)

Watts highlights the power idolatry has on people's lives and also reminds us to consistently take this perspective into consideration.

\section{Normative perspectives on the presence of God as basis for forsaking idols in the Decalogue (Ex 20:1-3)}

Douma (1996:15) views Exodus 20:1-3 as a framework of true worship of God and concludes that although idols exist as a reality alongside God, worshipping of them is forbidden. Motyer (1999:163-165) corresponds to this insight and describes the preface or prologue to the commandments as a declaration of God's relationship to Israel, which also influence their relationships with all other things and people. In the light of the discussion above, it is valid to conclude that true worship of God always starts with the right relationship with God. Cilliers (2000:132) makes an interesting comment on the preface to the commandments and indicates that through God's words, he came to his people. To them he said: 'I am the Lord thy God'. Through his presence, God assured his people of their freedom to worship and to serve him, and in that sense they received a new identity, namely people of God (Cilliers 2000:133; Long 2008:55; Meulen 2013:28).

We can speak about the grace of God's will through the prologue to the Ten Commandments (Douma 1996:19). The commandments are based on the words, 'I am the Lord thy God' (Watson 2001:17). He that will be, he that is, he that was, is the God (your God) that must be the supreme object of worship. It is this supreme God's right to determine how he will be worshipped (Vogt 2006:1999). Being committed to the Lord always excludes every possibility of idols (Douma 1996:18).

According to Sproul (1997:48) this means that a life in the presence of God entails that God's will transcends individual preferences, because it is an objective norm that must govern everybody's behaviour. The first commandment, 'Thou shall not have any other gods before $\mathrm{Me}^{\prime}$, is regarded as the root commandment (Cilliers 2000:135). The concept, before Me (al-panaja), is striking. Snodgrass (1990:111) indicates that the concept, before Me (al-panaja), has to do with the praesentia Dei [presence of God]. The expression, before Me (al-panaja), is also a human way of speaking about the supremacy of God, and it has the meaning of God's children realising that because he is present in their lives, they are in his service and there are no place for any idols (1990:112). The first commandment, 'Thou shall not have any other gods before $\mathrm{Me}^{\prime}$, addresses a wrong attitude against God and asks the question of which God is being worshipped (1990:118). What is the basis of realising the falsehood of idols or forsaking idols? It starts with a life of freedom in the presence of God 
and a realisation that a transfer of lordships has already taken place (1990:132). Through this transfer believers are living a life in Christ, or a life in the sphere of the lordship of Jesus Christ (in Christ - Rm 6:3-8, Col 3:1-2).

\section{Normative perspectives from 1 John 5:18-21}

To live and function in the presence of Christ (in Christ) also contains the assurance that believers are participating in Christ's victory. Floor (2002:169) underlines the purpose of the letter of John to exhort the believers to believe that they are victorious in Christ. Anyone who believes in Jesus Christ overcomes the world. Kruse (2000:194) also distinguishes the importance of the new life in Christ and motivates his answer by indicating that the concept, we know - oí $\delta \mu \varepsilon v$, is used three times in this passage. Floor (2002:169) accentuates the meaning of the word oí $\delta \mu \varepsilon v$ in saying that the concept, we know, is a solid knowledge and a kind of knowledge that has no doubt in it. Floor uses the concept, faith-knowledge. According to Anderson (1992:198) John applies three confirmations about the content of believers' faith, namely:

- We know that whoever is born of God, does not sin (1 John 5:18).

- We know that we are of God, and the whole world lies under the sway of the wicked one (1 John 5:19).

- We know that the Son of God has come and has given us an understanding (1 John 5:20).

It is evident from these verses that the devastating work of the evil (Devil) is a reality. The whole world lies in the power or

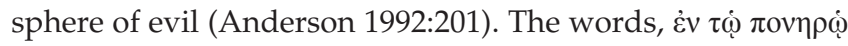
$\kappa \varepsilon i \tau \alpha 1$, can also denote something of 'lies in the grasp of' or 'is under the control of' (1992:200). The evil one takes persons under his control (Kruse 2000:196). It is important to note that John uses the term, the evil one, interchangeably with the term, devil (2000:195). In the letter of John there are five references to the evil one, namely 1 John 2:13, 2:14, 3:12, 5:18 and 5:19 (Wahlde 2010:206). Floor (2002:171) also describes it as being totally overwhelmed and overpowered by the work of the evil one. In contrast to the world, believers are not under the influence and power of evil (Floor 2002:171). In 1 John 5:20 there is something of a climax in the thought of John when he focuses on the knowledge of Jesus Christ (2002:171). The Son of God has come and has given God's children understanding (Kruse 2000:197). Kistemaker (1986:367) sees the contrast in these verses. Even if believers are seeing corruption because of the functioning of evil, they know that Jesus Christ has come and that he has given his children insight in his true nature. He revealed to us that God is the One who is true (Kistemaker 1986:367). The concept, Sióvolav, means insight (Floor 2002:171).

Having said that believers know God through the powerful work of Jesus Christ, it is important to note that believers are living in God and in Christ (Floor 2002:172). Tidball (2011) makes the following remark on 1 John 5:20 and 21:

The warning appears to stand in deliberate contrast to the verse before it, which speaks of Christians as 'in him who is true by being in his Son Jesus Christ. He is the true God and eternal life' (1 John 5:20). The implication is that Christian experience, as opposed to idol worship, is marked by truth rather than falsehood, authenticity rather than pretence, and life rather than death. So, instead of literal idols, John most probably had in mind the false teaching he has been denouncing in no uncertain terms throughout his letter, teaching that denied the real fleshand-blood humanity of the incarnate and the risen Christ and therefore preached a false and inadequate Saviour. (p. 14)

The admonition, 'little children, keep yourself from idols', comes without explanation in this passage (Kistemaker 1986:368). Kruse (2000:201) does not view this verse as an anti-climax, but something like a logical flow. Those who know the true God do not want to have anything to do with idols. Anderson (1992:203) brings to the foreground the meaning of the word $\varphi v \lambda \alpha \dot{\xi} \alpha \tau \varepsilon$ [guard yourself]. It could also mean 'be on your guard' or 'to keep from' (Wahlde 2010:207). Floor (2002:173) indicates that this imperative, to be on your guard, has to do with awareness very much like a shepherd that is aware of dangers his flock is facing. Kruse (2000:201) observes the element of a careful and watchful eye that believers need when it comes to idolatry. The word

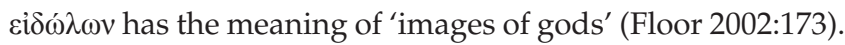
The idolaters in that time tried to experience something and therefore John makes the admonition that the only true way of experiencing is the way of faith in Jesus Christ (2002:174). Therefore this passage provides believers with the sole manner to shatter idols, namely the faith in Jesus Christ. This faith is the dynamite that shatters idolatry, specifically faith based on knowledge of the crucified and resurrected Lord.

Beale (2008:311) provides a concluding commentary on this verse by indicating that Jesus Christ has reformed God's children into his own image on the basis of his own Person, death, resurrection, and sending of the Spirit. Therefore he wants his children to trust him and not be idol worshippers. In other words, you become what you worship.

\section{Normative perspectives on the victory over the principalities and powers that underlie dehumanising power structures}

\section{A diabolic homiletic from Satan}

Campbell (2002:6) makes it clear that a normative investigation into dehumanising powers must take into consideration the encounter between the Word of God and the powers of death in the world. The principalities and powers in a postmodern world may have become more subtle, but are no less deadly. Floor (2001:107-108) makes a very interesting point by deducing that the Devil is not really original in his attack against God's kingdom. Where believers worship the true and only God, he wants to offer the 'so-called freedom' of idolatry. Where God's Word is proclaimed, Satan also wants to speak with a diabolic homiletic. This is why Luther called him the 'ape' of God (2001:107). The Satan is depicted in Scripture as the one that is always looking for ways of synchronisation or equalisation. In Acts 16:18 Paul proclaims the Name of Jesus Christ to 
show God's authority against the attempt of Satan to equate God and Satan's work (2001:110). Eswine (2008:232-238) also underlines the importance of the understanding and the functioning of Satan in proclaiming the attractiveness of idolatry. Eswine (2008:238) highlights the following aspects.

In John 8:43-44 Jesus refers to Satan as the father of lies. He delivers messages (sermons) and gets people to act according to his message. He is therefore a powerful preacher.

The devil uses words. His words are false and malicious against God and God's children. Satan's nature is the nature of an accuser.

There are two prominent examples of Satan's sermons in Scripture, namely the garden sermon and the wilderness sermon.

In the garden sermon (Gn 3) the devil tries to raise suspicion about God's authority and credibility. He also tries to add to what God has said. The problem is that he tries to subtract Adam and Eve from what God has said. Insight into this particular sermon helps preachers to recognise that something more than flesh and blood is working in society.

In the wilderness sermon (Lk 4), Satan raises suspicions about Christ's authority and credibility. In fact, he challenges Jesus' authority and identity. He also dares to apply words from Scripture out of context; he misuses God's Word. Modern preachers must understand the reality of Satan's influence behind attempts to challenge the Word of God and to sow discord regarding what God had said or had not said.

The parable of the sower and the seed (Mt 13:19) describes the on-going spiritual warfare in the hearts of those who have heard the Word of God (Eswine 2008:242). Idolatry and devilry have an enemy in the truth and vigorous life that flows from the Word of God. Preaching the Word of God is always an act of spiritual war. Preaching always encounters resistance, but on the other hand preaching is also an act of resistance against anything that stands in the way of the only and true God and the abundance of life that is his will for creation.

\section{Normative perspectives from Ephesians 6:10-12}

Divine grace and human responsibility are closely related in Ephesians 6:10-24. God gave the full complement of armour pieces, but the only way believers can employ them is by the power of God. In connection with this, Lloyd-Jones (1977:27) makes a very interesting comment, namely that the battle of believers is not in the first instance about them against the devil, but it is about God against the devil. It is God's war. The command to seek power in the Lord and in his might must be understood as the purposeful seek of believers to find their strength in the Lord (Roberts 1990:175). Olyott (2000:131) is concerned about over simplifying life. He (2000:132-133) takes his argument one step further and indicates that the life of a Christian is no hobby. It is not something believers can partake in for one or two days of the week. Therefore believers must realise that they are soldiers in God's war. The use of military terminology in Ephesians 6:10-12 is striking, depicting an intense struggle with words like strong, conflict, stand against and wrestle against.

In Ephesians 6:11 the method of the devil ( $\delta 1 \alpha \beta \circ \lambda \circ \varsigma)$ is described as crafty or trickery $(\mu \varepsilon \theta 0 \delta \varepsilon 1 \alpha \varsigma)$. Louw and Nida (1989:760) describe this concept as 'crafty scheming with the intention to deceive'. Against this scheming by the devil, the believers are adequately equipped by means of the amour of God. In Ephesians 6:12 believers are reminded of the fact that they are not wrestling against people, but against principalities, powers and rulers of the darkness of this age (Olyott 2000:134). Olyott (2000:134) also indicates that people persist in behaving in a way that God condemns, because their hearts and minds are controlled by other personalities and powers. Campbell (2002:11) observes that there is multiplicity in the working of principalities and powers. A diversity of concepts is used in the Bible to describe the characteristics of these principalities and powers, namely authorities, dominions, world rulers, thrones, demons, princes, strongholds, spirits of the air, dragons, lions and beasts. The powers that exist comprise all of the social, political and corporate reality in both visible and invisible manifestations. The spiritual reality of powers must not be minimised and must be seen in close connection to the embodiments through which they shape human life (Campbell 2002:16). Powers are capturing both from without and from within, and are also shaping the spirit of human beings. Powers are aggressive actors in this world.

In Ephesians 6:10-20 the power of the Holy Spirit holds a central place. Two aspects are highlighted in this passage, namely the Word of God as sword of the Spirit and the role of prayer. Without the vision for God's enabling power and work through the Holy Spirit, all believers and preachers will become despondent. Without this understanding, a sense of homiletic powerlessness tends to take hold of the hearts and minds of preachers and listeners. Eswine (2008:247) warns against the fact that hearers sometimes do not respond to sermons, because they understand very clearly what is being asked of them and as a result there is resistance. Preachers can become disheartened. Without a realisation of the work of the Holy Spirit in changing people's lives, also within the reality of idolatry, all preachers will feel vulnerable and powerless. On the other hand, preachers that do not proclaim this good message of the power of the Spirit against the powers of this world are neglecting their calling. The admonition to worship God alone and to stay away from idols without incorporating the message of the enablingwork through the Holy Spirit will inevitably end in legalistic preaching without any hope of endurance and perseverance. God's power - as it is ministered in his Word and joyfully embraced in prayerfully speaking to him - stands against the dehumanising powers and principalities of this world. In worshipping God all believers are strengthened with the knowledge that they are more that conquerors. 


\section{Homiletic theory for ministering the living presence of the crucified and resurrected Lord}

From the outset, we made it our priority to ask why proposals for change in a context of dehumanising power structures are usually met with obstinate resistance and to gain insight into the depth level of the underlying tension field. We tried to indicate that one possible way of exploring this depth level involves taking into account the hold of idolatry over the minds and hearts of human beings and the spiritual background in which it is imbedded. The question remains whether homiletic theory can bring new perspectives in the midst of resistance against sermons by attempting to address the reality of idolatry in the homiletic action field. Stott (2007:21) challenges the homiletic theory of preachers by indicating the need for sermons to enter the worlds of people without compromising Christian beliefs and values in the process.

In order to present a few anchor points, this matter can be addressed in the following ways:

Sermons can offer new perspectives in a South African context where the obstinate hold of idolatry has to be shattered in the hearts, minds and lives of people. Care should, however, be taken that it does not comprise a different kind of dehumanisation in the process. This can be called the forceful 'wrecking-ball' approach that wrecks everything in its path.

On the other side of the spectrum a preacher can, in trying to avoid the dangers of over assertive and manipulative communication, neglect the opportunity to proclaim the supremacy of God and his victory over abusive powers in a clear and bold manner. By deploying a soft, cushioning approach the preachers are in danger of not getting to grips with the obstinate hold of idols in their own heart and in the lives of the listeners.

As a third theological way - making use of the normative perspectives discussed in the previous section - perspectives are offered on the shattering impact of God's victorious presence in and through the gospel of the crucified and resurrected Christ. The ministry of this gospel, we believe, does not only shatter idols, but also humanises life into becoming truly free.

\section{Homiletical perspectives on an attempt to shatter idols by means of a forceful approach (The 'wrecking-ball' approach)}

Stott (2007:123) describes the task of preachers as a double act of listening. Preachers must listen to the Word of God with humility. The voices of the modern world are also important. When preachers are listening to the Word, they do it to believe and obey the Word. When they are listening to the world, they are doing it to understand the world and with the intention to proclaim the Word with sensitivity. Stott (2007:123) warns against the tendency or lust in society to worship power. The attraction of gaining power in the pulpit is more intoxicating than liquor and more addictive than drugs (2007:127). Preachers can easily become substitutes for the voice of the text in the sense that they think that they need to establish the effectiveness of their words by means of own persuasive power and insight. Brueggemann (2010:37) states that this in fact leaves preachers vulnerable and exposed, because it is their own voice against the voices of people in society. Hansen (2004:131) discusses the influence that the attitudes of preachers, in positioning themselves at a critical distance from the life and values of their hearers, can have on the way sermons are shaped. The wrong attitude of exercising control over hearers is destructive and dehumanising.

Robinson (2001:201) rightly indicates that the effectiveness of sermons depends on the content, but also on the way in which it is delivered. The attitudes of preachers are transmitted by their voices and gestures. Preachers cannot hide their attitudes. Tidball (2011:23) warns against the danger of making the pulpit an idol that can corrupt the motives and attitudes of preachers. Robinson (2001:203) determined from his research that inter alia only seven per cent of the preachers' message comes from their words. Thirty-eight per cent of the preachers' message comes from their voice, whilst 55\% comes from their facial expressions. Tidball (2011:41) highlights a very important aspect by distinguishing between authority and power. He refers to the example of a hearer asking the question: Why is the minister always angry on Sundays? This opens up the danger of the abuse of power. The power of the gospel can easily be replaced with the preacher's own ideas or oratory. When rightful power and authority become distorted, preachers are on the road to idolatry, (shaping preaching into an act of gaining pre-eminence by manipulating others; Tidball 2011:45). Stott (2007:129) highlights the power of preaching, namely as power through the weakness of the gospel itself. Divine power manifests in human weakness. Preachers can easily create the impression in a hearer's hearts that they are using the Word of God to gang up against them. In a South African context, preachers can be guilty of preaching the imperative of 'you shall not worship idols'. Without the strong indicative of the supreme God, their sermons can become legalistic (Cilliers 2000:78). Imperatives regarding idolatry and sermons that address the two examples discussed in this article will become legalistic if it is happening outside the circle of God's grace. Preaching about idolatry must be anchored in the grace of obedience to the One and Only God (2000:89). Without the message of the cross of Jesus Christ and his victory, preaching can become a dehumanising act.

\section{Homiletical perspectives on a soft approach that neglects the hold of idolatry (The cushioning approach)}

The preceding paragraph makes the point that preaching can become dehumanising because of forceful attitudes and wrecking-ball sermons that flow from these attitudes. This paragraph pays attention to the opposite approach - the socalled cushioning approach. Buttrick (2007:63) is sensitive for what he calls 'careless-preaching' in the sense that this kind of 
preaching can become a testimony to unbelief. Preachers who live and preach with the insight of God's presence in their hearers' lives cannot become careless. Tidball (2011:55-57) explains the idol of popularity in preacher's ministries. The danger is that preachers like to be liked. In this process, preachers can become guilty of taking the directness of Scripture away by formulating their sermons in such a way that hearers would not feel uncomfortable. To follow a cushioned approach towards preaching is to trim the truth, and it is an attempt to demote the importance of the meaning of the text. To preach in a cushioned manner can also become idolatry because of the fact that popularity can become an idol, instead of the true and living God (2011:58).

We agree with Long (2005:52) when he states that preaching is biblical whenever the preacher allows a text to serve as the leading force in shaping the content and the purpose of preaching. However, Long opens up the question that If the God of the Bible exists, what is wrong with preaching in our contemporary societies? Why is it possible that preachers can neglect the importance of daily realities in society (with cushion approaches) to such an extent that society can be called a neglected society? Craddock (2000:4) makes an interesting point when he says that the judgements of critical voices against preaching are not always the result of a disinterest in religion or preaching, but more of a reaction against preachers that create a caricature in the pulpit. The consequence is that preaching can easily become a dysfunctional instrument and preachers can become irresponsible escapists, instead of preaching the realities of the kingdom of God and the realities in society (Stott 1999:18). A cushioning approach is not a responsible approach.

\section{Shattering idols with the power and wisdom that flows from the living presence of God in the crucified and resurrected Lord}

If the options of the 'wrecking-ball' approach and the option of a soft approach that neglects the hold of idolatry are not responsible options, what must preachers do to be responsible? Although we are just touching the tip of the iceberg, we want to offer three anchor points in our homiletic theory. These anchor points proceed from the normative perspectives on the presence of God as basis for forsaking idols in the Decalogue, the normative perspectives from I John 5:18-21 and also the normative perspectives on the victory over the principalities and powers that underlie dehumanising power structures. We also bring our homiletic theory into dialogue with the two examples of obstinate power systems in post-apartheid South African society (as discussed in the section: examples of the resilient power systems in a post-Apartheid South African society) in the concluding part of the article.

\section{God's victorious presence in and through the lordship of Jesus Christ}

In the normative section of this research attention was paid to the first commandment, 'Thou shall not have any other gods before $\mathrm{Me}^{\prime}$. The question was what the basis is of realising the falsehood of idols and how to forsake them in the process. This discussion shows that it starts with a life of freedom in the presence of God and the realisation that a transfer of lordship has already taken place. Believers are living a life in Christ, or a life in the sphere of the lordship of Jesus Christ. Only in this sphere of praesentia realis can the power of idolatry be broken and shattered. Obedience to the first commandment is also the key to obedience to all the other commandments.

The realisation of the fact of coram Deo and the presence of God in our lives must inspire preachers and hearers to become active in the liturgy of life. Presenting the victorious presence of the living God in and through the gospel of the lordship of Jesus Christ will be the homiletic base for exposing the foolishness of trying to secure a worthwhile life by means of idolatry.

\section{Faith knowledge rooted in the crucified and resurrected Lord as dynamite in shattering idolatry}

In this article the authors intend to indicate that it is important to note that there are principalities and powers behind the functioning of idolatry. To name the reality of idolatry in preaching, a person must have the starting point in the victory of Jesus Christ and the living faith of living in Christ. This living faith is powerful, because it offers the perspective of God's supremacy above everything. The challenge is to refrain from preaching in such a way that hearers become negative and want to withdraw from society. Rather enable them to be witnesses in society against the functioning of idolatry. In contrast to the world, believers are not helplessly in the grip of the influence and the power of evil. The Son of God has come and has given his children understanding that, although believers see corruption because of the functioning of the evil, they know that Jesus Christ has come and that he has given his children insight into his true nature. $\mathrm{He}$ revealed to us that God is the One who is true.

Campbell (2002:62) indicates that it is important to proclaim that the principalities and powers behind idolatry were paraded before believers as the powers of death. They were exposed and the mirrors by which they maintained their reign were removed. Through the conquering work of Jesus Christ (as dynamite) humanity has been freed from enslavement from the captivity of domination from the powers (2002:63). With this view as vantage point, it is also important to preach the implications of the faith perspective that these fallen and shattered powers, although they have been mortally wounded, still, in their final death throes, have a deeply destructive effect on the world in its current state. Believers are living in this tension of already and not yet (the so-called eschatological tension). Without recognition of this perspective and God's promises preaching will become an oversimplification of reality.

The contribution of Eswine (2008:230), who advises preachers to understand God's controversy with idols and idolatry as 
the main controversy in the world, has implications for the preacher's sermon preparation. Eswine (2008:230) suggests that preachers must have an encounter with the Word and must have insight into the context of hearers. Preachers must carefully examine the various superstitions that blind people to such an extent that they become unaware of the presence of the living God. The authority of preachers in preaching about idolatry is inherently embedded in the certainty about the cross and resurrection of Christ. Therefore, hearers listen to sermons with the knowledge of victory and this insight is an idol shattering anchor in their battle against principalities and powers.

\section{Perspectives on the enabling work of the Holy Spirit}

Idolatry and devilry have an enemy in the truth of the Word of God, and preaching of the Word should be seen as an act of spiritual warfare. Preaching always encounters resistance, but on the other hand, preaching is also an act of resistance against anything that stands in the way of the only true God. Preaching about idolatry must acknowledge the fact that the persuasion of hearers is dependent on the powerful work of the Holy Spirit, and should not depend anthropocentrically on abilities like rhetorical speech and skills of preachers. In this case the Word of God is called the sword of the Holy Spirit. When preachers proclaim God's Word, they are doing it with the faith that God is present through his Spirit. The Spirit uses the Word as sword (Eswine 2008:251). Therefore preachers do not have to avoid the directness of God's Word and their dependence on the Spirit offers boldness in sermon delivery. Preachers must pray for this boldness and hearers must learn to live through the power of prayer in their daily struggle against idolatry. To pray is to acknowledge our dependence upon the power of the Spirit (Eswine 2008:257).

\section{Conclusion}

Regarding the implications of our homiletic theory for the two examples that were discussed earlier, the following hold water.

In the context of the growing number of labour-related protests as it culminated in the Marikana incident, we asked to what extent the brutality and exceeding violence that surfaced during this unfortunate event was triggered by a desperate attempt to protect the own idol of selfaggrandisement from being threatened by the masses. To our mind the obstinate hold of self-aggrandisement and its dehumanising effect of treating the protestors merely as objects of economic threat and not as human persons, can only be broken by exposing the foolishness of this mind set. Only by ministering the living presence of God, as it manifests in the falsehood-disclosing and death-conquering presence of the crucified and resurrected Jesus Christ in the homiletic event, can listeners see the truth about the falsehood of their idols and can they be persuaded to forsake their idols. A sermon should be prepared and delivered with the prayerful faith expectation that the Spirit of the crucified and resurrected Lord will shatter all illusions and this should make the reality of allowing oneself to become an instrument of violent powers unbearable. Only then will the preacher and listeners be able to anchor the meaning and purpose of their lives in eternal communion with the living God; and will they be able to see that the kingdom of heaven opens up such a rich abundance of life that human beings need not to be seen any longer as mere economic threats any longer.

The so-called White Talk is also referred to as a means through which white people attempt to position themselves within an Africanising context, and failing to realise that their preoccupation with their own privileges are potentially estranging themselves from their fellow South Africans in the process. To our mind the obstinate hold of the preservation of the own privileged position as idol, can in this case only be broken by exposing the foolishness of this mind-set. By prayerfully confronting listeners with the living presence of the God that conquered the powers of hate, fear and estrangement with his eternal love as it is illustrated in the triune community, all illusions of what life-protective community actually entails, can be shattered. The lives of the listeners should be homiletically anchored in Christ and the reconciliatory power that flows from communion with him. In this way the focus can be shifted away from seeing the other as unfair competition in a playing field where there are limited resources. Fellow South Africans will rather be seen as fellow human beings whose lives can be enriched and ministered by the abundant resources that are freely available to us in Christ. White Talk with its deceptive rhetoric and estranging effect will be replaced by Kingdom Talk, speaking humanising words that prepare fellow South Africans for true reconciliation and for embracing the abundance of life freely available to them all in God's living presence.

\section{Acknowledgements Competing interests}

The authors declare that they have no financial or personal relationship(s) that may have inappropriately influenced them in writing this article.

\section{Authors' contributions}

F.W.d.W. (North-West University) wrote the section on the de-humanising powers, whilst F.P.K. (North-West University) wrote the section on the normative perspectives. Both authors contributed to the rest of the article.

\section{References}

Achtemeier, E., 2000, Preaching from the minor prophets, Eerdmans, Grand Rapids.

Anderson, J.L., 1992, An exegetical summary of I, II and III John, Academic Bookstore, Dallas.

Beale, G.K., 2008, We become what we worship: A biblical theology of idolatry, IVP Academic, Nottingham.

Bond, P. \& Mottiar, S., 2013, 'Movements, protests and a massacre in South Africa', Journal of Contemporary African Studies 31(2), 283-302. http://dx.doi.org/10.10 80/02589001.2013.789727

Bongmba, E.K., 2006, Dialectics of transformation in Africa, Palgrave Macmillan, New York. http://dx.doi.org/10.1057/9781403984586 
Brueggemann, W., 2010, The Word militant: Preaching a decentering Word, Fortress, Minneapolis.

Buttrick, D., 1987, Homiletic: Moves and structures, Fortress, Philadelphia.

Buttrick, D., 2007, 'The folly of preaching', in M.P. Knowles (ed.), Taking the listeners seriously as people of God, pp. 63-65, Eerdmans, Michigan.

Campbell, C.L., 2002, The Word before the powers: An ethic of preaching, Westminster, Louisville.

Cilliers, J., 2000, Die genade van gehoorsaamheid, Lux Verbi, Kaapstad.

Craddock, F.B., 1985, Preaching, Abingdon, Nashville.

Craddock, F.B., 2000, As one without authority, Chalice Press, Saint Louis.

Dingemans, G.D.J., 1996, Als hoorder onder de hoorders: Hermeneutische Homiletiek, Kok, Kampen.

Dingemans, G.D.J., 2005, De stem van de Roepende: Pneumatheologie, 4e herz. dr., Kok, Kampen.

Douma, J., 1996, The Ten Commandments: Manual for Christian life, P \& R Publishing, New Jersey.

Elshtain, J.B., 2011, 'Between heaven and hell: Politics before the end-time', Process Studies 40(2), 215-226. http://dx.doi.org/10.5840/process201140233

Eswine, Z., 2008, Preaching to a post-everything world, Baker Books, Grand Rapids.

Fouche, L., 1999, Sewe: Jou kompas tussen lig en duister, Lux Verbi, Kaapstad.

Floor, L., 2002, De leer van Christus: Practische commentaar op de brieven van Johannes, Groen, Heerenveen.

Goudzwaard, B., 1984, Idols of our time, InterVarsity, Downers Grove

Hansen, D., 2004, 'Who's listening out there?', in H. Robinson, B. Chappel, D. Sunukijian \& S.M. Gibson (eds.), Preaching to a shifting culture, pp. 129-147, Baker Books, Grand Rapids.

Heisey, N.R., 2011, 'Paul on idolatry: Finding fruitful fellowship', Vision 12(1), 43-50.

Horstkoetter, D., 2013, 'Getting back to idolatry critique: Kingdom, kin-dom and the triune gift economy', Union Seminary Quarterly Review 64(2-3), 86-100.

Johnston, M., 2009, Saving God: Religion after idolatry, Princeton University Press, Princeton. http://dx.doi.org/10.1515/9781400830442

Keller, T., 2009, Counterfeit gods: The empty promises of money, sex, and power and the only hope that matters, Riverhead Books, New York.

Keller, T., 2012, 'A new kind of urban preacher', in F. Chan, J. Ortberg, T. Keller, M. Buchanan, A.G. Lotz et al. (eds.), Prophetic preaching, pp. 81-89, Hendrikson Publishers, Massachusetts.

Kistemaker, S.J., 1986, James and I-III John, Baker Book House, Grand Rapids. (New Testament Commentary).

Kruse, C.G., 2000, The letters of John, Apollos, Leicester. (The Pillar New Testament Commentary).

Lloyd-Jones, D.M., 1977, The Christian soldier, Banner of Truth, Edinburgh.
Long, T.G., 2005, The witness of preaching, Westminster John Knox, Louisville.

Long, T.G., 2008, 'The folly of preaching', in M.P Knowles, (ed.), Taking the listeners seriously as people of God, pp. 43-59, Eerdmans, Grand Rapids, MI.

Long, T.G., 2009, Preaching from memory to hope, Westminster John Knox, Louisville. Louw \& Nida, 1989, Greek English lexicon of the New Testament, vol. 1, United Bible Studies, New York.

Meulen, P., 2013, Woorden van leven, Medema, Heerenveen.

Motyer, J.A., 1999, The message of Deuteronomy, InterVarsity, Leicester. (The Bible speaks).

Olyott, S., 2000, Alive in Christ, Evangelical Press, Darlington.

Osmer, R., 2008, Practical Theology: An introduction, Eerdmans, Grand Rapids.

Piper, J., 2012, 'The supremacy of God in preaching', in J. Piper, G. Macdonald, S. Chapman, B. Wilerson \& H. Robinson et al., Inspirational preaching, pp. 9-19, Hendrikson Publishers, Massasuchets.

Roberts, J.H., 1990, Teologie in konteks, Perskor, Johannesburg.

Robinson, H.W., 2001, Expository preaching: Principles and practice, Baker House, Grand Rapids.

Satgar, V., 2012, 'Beyond Marikana: The post-apartheid South African state', African Spectrum $47(2-3), 33-62$.

Snodgrass, K., 1990, Between two truths: Living with biblical tensions, Zondervan, Grand Rapids.

Sproul, R.C., 1997, Playing God, Baker Books, Grand Rapids.

Steinbeck, J., 1999, The grapes of wrath, Penguin Books, New York.

Steyn, M. \& Forster, D., 2008, 'Repertoires for talking white: Resistant whiteness in post-apartheid South Africa', Ethnic and Racial Studies 31(1), 25-51. http://dx.doi. org/10.1080/01419870701538851

Stott, J., 1999, New issues facing Christians today, Zondervan, Michigan.

Stott, J., 2007, The living church: Convictions of a lifelong pastor, InterVarsity, Nottingham.

Tidball, D., 2011, Preacher, keep yourself from idols, InterVarsity, Nottingham.

Van der Walt, B.J., 1999, Kultuur, lewensvisie en ontwikkeling, Instituut vir Reformatoriese Studies, Potchefstroom.

Vogt, P.T., 2006, Deuteronomic theology and the significance of the Torah, Eisenbrauns, Winona Lake.

Wahlde, U.C., 2010, The gospel and the letters of John, Eerdmans, Grand Rapids. (Eerdmans Critical Commentary).

Watson, T., 2001, The Ten Commandments, Offset Lithography, Edinburgh.

Watts, C.M., 2012, 'Christian worship and American idolatry', Encounter 72(3), 21-41.

Weidler, M., 2012, 'Heidegger's "Fourfold” as a critique of idolatry', Monatshefte 104(4), 489-510. http://dx.doi.org/10.1353/mon.2012.0115 